11. Yas, O.V. (2009). «Svii» sered «chuzhykh», «chuzhyi» sered «svoikh». «Ystoryia Maloi Rossyy» D. Bantysha-Kamenskoho u svitli ukrainsko-rosiiskoho kulturnoho perekhrestia (do 220-richchia Dmytra Bantysha-Kamenskoho). [«Yours» among «strangers», «strangers» among «your own». «History of the Little Russian» by D. Bantysh-Kamensky in the light of the Ukrainian-Russian cultural crossroads (220-year-old Dmitry Bantysh-Kamensky)]. Ukrainskyi istorychnyi zhurnal - Ukrainian Historical Journal, 2, 160-194 [in Ukrainian].

Одержано 18.04.2019.

УДК 94:[001:37-051(477)«1985/1991»

Потапенко Руслана,

викладач кафедри історії та культури України

rusyapotapenko007@gmail.com https://orcid.org/0000-0002-3521-9462

Державний вищий навчальний заклад «Переяслав-Хмельницький державний педагогічний університет імені Григорія Сковороди», вул. Сухомлинського, 30, м. Переяслав-Хмельницький, Київська обл., Україна, 08401

\section{DOI https://doi.org/10.31470/2415-3567- 2019-46-225-232}

\section{Potapenko Ruslana,}

Lecturer of the Department of History and Culture of Ukraine rusyapotapenko007@gmail.com https://orcid.org/0000-0002-3521-9462

Pereiaslav-Khmelnytskyi Hryhorii Skovoroda State Pedagogical University, 30, Sukhomlynsky Str., Pereiaslav-Khmelnytskyi, Kyiv region, Ukraine, 08401

\title{
НАУКОВО-ОСВІТНЯ ІНТЕЛІГЕНЦІЯ В ПРОЦЕСАХ ТРАНСФОРМАЦЇ̈ УКРАЇНОЗНАВЧИХ СТУДІЙ В ПЕРІОД СУСПІЛЬНО-ПОЛІТИЧНИХ ПЕРЕТВОРЕНЬ (1985-1991)
}

У статті простежено як радянська влада боролася з проявами національної свідомості в Украӥні. Висвітлено актуальні питання щцодо украӥнознавчого аспекту дослідження історії України в добу Перебудови (1985-1991 рр.). Адже, в формуванні національної самосвідомості українського народу важливе значення посідало відновлення історичної пам'яті, осмислення або переосмислення історичної місії в контексті загальночивілізаційного поступу. Важливу роль в даних процесах відігравали вчителіпатріоти, науковиі, які підтримували ідею незалежної $і$ суверенної Украӥни. Формуючи украӥнську націю вони звертали свої погляди на украӥнознавство, а уроки з даної тематики сприяли усвідомленню приналежності до певного народу, який має свою історію, культуру, духовну спадщину.

На долю українського народу випали важкі випробування, які були викликані іï колоніальним поневоленням, особливо в частині національної самобутності. Для досягнення результату використовувалися всі методи, засоби, починаючи від демагогії, утисків, фальсифікацій, заборон і закінчуючи нищенням, репресіями національної еліти, інтелігениії, щзо становила ядро нації.

У часи Перебудови виникла ідея стосовно створення першого в Україні науковоосвітнього центру, який би займався виріменням практичних завдань, а саме - творив би національну освіту, науку, виховання. Так за інічіативи декана філологічного факультету Київького державного університету імені Тараса Шевченка П. Кононенка в 1988 р. було створено Центр українознавства. 
Ключові слова: науково-освітня інтелігенція, українознавство, Перебудова, національна свідомість, фольклор, вчителі-патріоти.

\section{SCIENTIFIC AND EDUCATIONAL INTELLIGENCE IN THE PROCESSES OF TRANSFORMATION OF UKRAINIAN STUDIES IN THE PERIOD OF SOCIAL- POLITICAL TRANSFORMATION (1985-1991)}

The article traces how the Soviet authorities fought the manifestations of national consciousness in Ukraine. Investigated topical issues concerning the Ukrainian-scientific aspect of the history of Ukraine in the period of Perestroika (1985-1991) are highlighted. Because, in the formation of national consciousness of the Ukrainian people restoring historical memory was important, comprehending or rethinking a historical mission in the context of a civilizational progress. An important role in these processes was played by patriot teachers, scholars who supported the idea of an independent and sovereign Ukraine. Forming the Ukrainian nation, they turned their sights on Ukrainian studies, and lessons on the subject contributed to the awareness of belonging to a particular nation, which has its history, culture, and spiritual heritage.

The Ukrainian people have had difficult trials, which were caused by its colonial enslavement, especially in terms of national identity. To achieve the result were used, all methods, tools, from demagogy, oppression, falsification, prohibitions and ending with the destruction, repression of the national elite, the intelligentsia that formed the nucleus of the nation.

At the time of Perestroika the idea arose to create the first scientific and educational center in Ukraine to deal with practical problems, namely - would create national education, science. Thus, at the initiative of the Dean of the Faculty of Philology P. Kononenko Kyiv Taras Shevchenko State University, the Center for Ukrainian Studies was established in 1988.

Key words: scientific and educational intelligentsia, Ukrainian studies, Perestroika, national consciousness, folklore, patriots teachers.

Пошук ефективних та дієвих методів розбудови незалежної України ставить питання всебічного аналізу історичного досвіду, зокрема трансформаційних процесів в сфері краєзнавства на зламі періоду Перебудови (1985-1991 рр.). Проблема залишається малодослідженою, оскільки на заваді цьому стоять деякі стереотипи, сформовані у свідомості цілого покоління зусиллями радянської пропаганди. Актуальність дослідження зумовлюється потребою усунення «білих плям» у нашій історії, відновленню історичної справедливості.

Мета даної статті - з'ясувати місце та роль українознавства в освітньому процесі УРСР періоду Перебудови; показати, які трансформації відбулися в краєзнавчій роботі за безпосередньої участі науково-освітніх працівників із запровадженням політики гласності.

Нові соціально-політичні умови, які склалися в добу Перебудови в Україні, політика гласності сприяли зростанню національної свідомості. Вивчення минулого історичної науки набувало теоретичного та практичного значення, що ставало можливим за рахунок розкриття «білих плям» в історії та розвінчування культу особи. Розбудова нової концепції української історії була не можлива без усвідомлення своєї історії, історичної пам'яті. Тому науково-освітні працівники активно включилися в цей процес і не в останню чергу за допомогою популяризації власної культури, фольклору, історії. Так в цей період починають активно з'являтися краєзнавчі та народознавчі дисципліни.

У формуванні національної самосвідомості українського народу важливе значення посідало відновлення історичної пам'яті, осмислення або переосмислення історичної місії в контексті загальноцивілізаційного поступу. Це питання можна було вирішити лише за допомогою цілісної науки про етнос, націю і народ України. 3 кінця ХХ ст. такою наукою стає українознавство. Фундамент було закладено ще такими ученими-укрїнознавцями як 
М. Максимович, М. Грушевський, В. Вернадський, Д. Дорошенко, Д. Багалій тощо. Примітно, що 3 кінця 1920-х pp. через згортання політики українізації робота призупинилася. В подальшому розвиток науки відбувався переважно за межами Радянської України. Цю роботу робили вчені діаспори та науковці, які гуртувалися навколо НТШ у Львові [7, с.107]. Відродження українознавства починається в 1960-70-х pp. Зокрема, В. Нічик розгорнула дослідження філософського підгрунтя освіти в КиєвоМогилянській академії. Далі в цьому українознавчому напрямку працювали такі дослідники: І. Бичко та А. Бичко, С. Бондарь, В. Горський, I. Захари, В. Ісаєвич, М. Кашуба тощо [17, с.71].

Якщо зробити невеликий екскурс в історію, то ми можемо побачити, що до 1918 р. в Україні не було державних шкіл з українською мовою навчання. Царська Росія проводила політику русифікації, денаціоналізації населення, онімеченню, мадяризації слугувала школа на західноукраїнських землях. Революційні події дещо посприяли національній культурі та освіті, але командно-адміністративна система, культ особи все це жорстко гальмував. Зневага та нехтування національно-культурними потребами, традиціями українців загострила мовне питання та посилила проблеми розвитку освіти і культури. Масові репресії проти національної інтелігенції, мали трагічні наслідки для України. Але попри всі вищеперераховані обставини українська освіта розвивалася. Про це свідчить такий приклад: до революції в Україні було 27 вищих навчальних закладів в яких навчалося 35 тис. студентів, а в часи Перебудови у 9 університетах, 138 інститутах, 738 середніх спеціальних учбових закладах навчалося 1,7 млн. чоловік [9, с. 204].

Звернення до всього українського, свого, можна було зреалізувати за допомогою українознавства. Таким чином можна було реалізувати національну ідею, сформувати громадську свідомість. Вчителі-патріоти, науковці, які підтримували ідею незалежної і суверенної України, формували українську націю, звернули свої погляди на українознавство призму інтересів українського народу, а уроки українознавства сприяли усвідомленню приналежності до певного народу, який має свою історію, культуру, духовну спадщину.

За переконанням науковців НДІУ МОН України українознавство - це не стільки знання про все потроху, не мозаїчне утворення різних кольорів, а єдина наука цілісного пізнання й самопізнання України й українства 3 метою дослідження їх феномена, закономірностей розвитку, шляхів і засобів самотворення. Українознавство - не тільки і не скільки наука про минуле, скільки про сучасне і неодмінно майбутнє українського народу [14, с. 164].

Згідно іншого трактування, українознавство - це система етнологічних, культурологічних, етнопедагогічних, історичних та інших досліджень про український народ у його минулому та сучасному розвитку [3, с. 414].

За концепцією Науково-дослідного інституту українознавства МОН України українознавство - це цілісна інтегративна система знань про Україну, українців, українство як геополітичну реальність, що сприяє виробленню моделі розвитку української спільноти на основі пізнання себе як етносу, нації і держави у минулі часи та сьогодні в полікультурному середовищі і часопросторовій взаємозалежності [8, с. 114].

На рубежі 80-90-х pp. ХX ст. розпочинається суспільно-політичне і культурне відродження. Все це підкріплювалося різними науковими дослідженнями, які стали можливими завдяки розвінчуванню замовчуваної століттями історії. 3'явилася плеяда науковців, які прагнули показати правду, і в даному руслі вони аналізували історію, побут минулого та сучасного. Це, в свою чергу, показало існування величезної цивілізаційної проблеми українського народу щодо формування та розвитку національної ідеї, нації. Оскільки, царська Росія, а згодом і іiі правонаступниця СРСР тотально денаціоналізує Україну, перетворює республіку на колонізовану частину. На думку П. Кононенка «...народ без історичної пам'яті $є$ не народом, а тільки населенням...так і народ без власної ідеї розвитку не є нацією» [6, с. 22]. 
На долю українського народу випали важкі випробування, які були викликані їі колоніальним поневоленням, особливо в частині національної самобутності. Все це розпочалося з давніх-давен. Цікавим є приклад, коли згідно царського указу 1721 р. було введено цензуру на українські книги. Указом 1769 р. було заборонено викладання української мови в Києво-Могилянській Академії. Укази 1769 і 1886 рр. стосувалися доплати російським чиновникам за русифікацію в Україні. У 1881 р. виходить заборона викладати українську мову в народних школах. В 1983 р. згідно постанова ЦК КПРС, вчителі російської мови в Україні отримували 15\% надбавку до заробітної плати в порівнянні 3 учителями української мови тощо. Для досягнення результату використовувалися всі методи, засоби, починаючи від демагогії, утисків, фальсифікацій, заборон і закінчуючи нищенням, репресіями національної еліти, інтелігенції, що становила ядро нації.

Досить складними були дані процеси на Гуцульщині в 1970-80-х рр. культурні надбання цього регіону називали «патріархальщиною», «націоналістичними пережитками» i тому радянська система ставила перед собою завдання посиленої боротьби 3 ïx подолання. Піддавалися забороні наукові дослідження культурноісторичних процесів цього регіону. Обмежувався доступ до наукової літератури стосовно звичаїв, традицій, культури гуцулів, публікації наукових матеріалів тощо. Все це намагалися замінити вивченням історії КПС, наукового комунізму, політекономії. Але на щастя, всі ці імперсько-шовіністичні ідеї та фальсифікації історичних процесів саме на Гуцульщині були малоефективними і регіональна самоідентифікація, самобутність там збереглася досить добре [18, с. 229-240].

Примітною $є$ думка кандидат історичних наук Л. Токар, який вказував, що тип наукового мислення почав змінюватися лише у другій половині XX - поч. XXI ст. Це ставало можливим завдяки впливам на неї новітніх досягнень суспільних та природничих наук, розвитку свідомості. 3 цього часу наука від досліджень переважно предметного складу речей починає вивчати процеси і тенденції розвитку, функціонування цілісних систем. Так, на початку 1990-х рр. було обгрунтовано наукову концепцію українознавства як цілісної системи знань, як науки, навчальної дисципліни, було розроблено освітні програми, підручники [15, с. 25-26].

На думку Т. Усатенка, неможливо пробудити національну свідомість без переосмислення та переживання історичного шляху народу, зокрема освітніх, виховних, навчальних традицій, особливо без розвінчування педагогічних та ідеологічних міфів [16, c. 38].

Безперечним є факт, що царська Росія, а згодом радянська пропаганда насаджувала антиукраїнську ідеологію. Так, Київську Русь інтерпретували, як «спільну колиску братніх народів», Переяславську угоду як «возз'єднання України з Росією», Центральну Раду як «орган української контрреволюційної буржуазії», а національно-визвольних героїв як «зрадників», «бандитів», «запроданців». Процес національного самоусвідомлення був досить складним, особливо в зросійщених регіонах. Національній самоідентифікації заважав ще й такий феномен як «російськомовні українці» [2, с. 42].

Довгий час в країні національне відродження трактувалося як «націоналістичні прояви» до «націоналістичних проявів» радянська влада зараховувала: «...роздування національної специфіки, ідеалізацію історичного минулого своєї нації або народності; національний егоїзм...ігнорування національних особистостей та інтересів інших націй..., їх мови, культури, звичаїв...» [10, с. 60-61]. Трактування ленінської національної політики по-різному за радянських часів призводило до критики за «націоналістичні прояви». Така позиція призводила до того, що в одних випадках любов до свого народу піддавалася жорсткій критиці, а в інших - на неї не звертали увагу. Українське національне відродження мало свою особливість, а саме - стрімкий розвиток суспільно-політичної думки та суспільно-політичних процесів. Це засвідчує результат всесоюзного референдуму 17 березня 1991 р. і всеукраїнського референдуму 1 грудня 1991 р. 
Національно-культурне відродження перетворилося на боротьбу за суверенітет УРСР на засадах Конституції СРСР і до проголошення незалежності [10, с. 60-62].

Через призму діяльності окремих осіб ми краще сприймаємо власну історію, культуру нашого народу. Серед видатних постатей 2-ої пол. XX ст. можна виокремити Анатолія Мокренка. 31985 р. А. Мокренко професор кафедри вокального співу Київської державної консерваторії імені П.І. Чайковського. Творчість науковця віддзеркалювала любов до історії України. Протягом 1985-1990рр. разом з Г. Майбородою (педагог, композитор) та О. Ющенком (член Спілки письменників) брав участь у всіх заходах стосовно боротьби за незалежність. А. Мокренко наголошував, що народ гуртується навколо національної ідеї, але носієм цієї ідеї завжди є особистість. В 1990 р. А. Мокренко виступив ініціатором святкування 500-річчя від дня заснування Чортомлицької Січі. Завжди переймався кобзарською справою в Україні. Брав участь в установчому з'їді кобзарів України 31 травня - 1 червня 1990 р., створенні Спілки кобзарів України. Підтримував мистецькі зв'язки 3 першою кобзарською школою, організованою в с. Стрітівка на Кагарличчині. У своїх виступах як в Україні, так і за іï межами популяризував українську народну пісню, а також відомого краєзнавця Ф. Сахна 3 Роменщини [1, с. 41-42].

Внесок Феодосія Сахна - краєзнавця, також тяжко переоцінити. Він зробив спробу через минуле Смілого осмислити історію всієї України. Так, до «Історії Смілого» ввійшли тисячі документів та публікацій, перекази, легенди, пісні земляків. Ним було записано багато з історії рідного краю очевидцем чого він був сам [12].

Великий внесок в розвиток українознавства, історії, вивчення рідного краю зробив Дмитро Білоус. Творчість Д. Білоуса стосувалася тематики рідної мови, мовознавства. Так, у 1988 р. вийшла книга «Диво калинове». У ній йшлося про красу рідної мови, про іiі таємниці. Автор намагався навернути людей до української культури, побуту, звичаїв. Показати красу, самобутність українського народу, мови тощо [11, с. 246-254].

В часи Перебудови виникла ідея стосовно створення першого в Україні науковоосвітнього центру, який би займався вирішенням практичних завдань, а саме творити національну освіту, науку, виховання. Так, за ініціативи декана філологічного факультету Київського державного університету імені Тараса Шевченка П. Кононенка в 1988 р. було створено Центр українознавства при факультеті. Перед інтелігенцією постала низка проблем: Як далі жити в Україні? Як рухатися далі? «Криза ж системи зумовлює кризу освіти, а та, в свою чергу, поглиблює загальну кризу суспільства» і як наслідок «... суспільство в стані ідейного бродіння з ознаками тотальної кризи» [13, с. 208]. Тому, українознавство постало як нагальна потреба тогочасного суспільства, як необхідна універсальна наукова система.

3 березня 1991 р. розпочало свою роботу громадське освітньо-наукове об'єднання 3 назвою «Інститут українознавства», в основу якого лягла концепція П. Кононенка про універсальну цілісність України й українства. Напрямки роботи визначала розроблена програма «Інституту українознавства»: мова, етнос, природа, екологія, історія, суспільство, держава, господарство, релігія, філософія, культура, громадсько-політична думка, освіта, наука, право, педагогіка, мистецтво, геополітика, міжнародні відносини тощо. Для реалізації намічених цілей необхідна була консолідація професійних сил. Ректору Київського державного університету була зроблена пропозиція при університеті створити інститут українознавства. До 31 грудня 1991 року рада університету зобов'язала ректора видати відповідні накази. Але відповідні накази видані не були. Новий освітньонауковий підрозділ - Інститут українознавства - розпочав свою діяльність лише з січня 1992 р. [13, c. 207-209].

Примітним був і той факт, що в часи перебудови активізували свою роботу раніше відкриті Інститут українознавства ім. І. Крип'якевича та Інститут народознавства у м. Львові. Вчені цих інститутів зробили значний внесок у вивчення та популяризацію української культури, історії, фольклору, етнографії та мистецтвознавства $[4 ; 5 ; 13]$. 
Таким чином, політика гласності, відкриття «білих плям» в історії сприяло вивченню та переосмисленню історії, а це, в свою чергу, стимулювало зростання національної свідомості. Вивчення минулого історичною наукою з теоретичної площини переходить в практичну. Зокрема, було розроблено нову концепцію з українознавства. Попри те, що царська Росія, а згодом і ії правонаступниця СРСР за допомогою демагогії, фальсифікацій, заборон, репресій зробила все можливе, щоб знищити національну самобутність українців, український народ вистояв і не в останню чергу за допомогою науковоосвітньої інтелігенції, яка була рупором, беззаперечним авторитетом в часи соціальнополітичних перетворень, механізмом збереження побуту, звичаїв, фольклору, націоналістичних тенденцій.

\section{ДЖЕРЕЛА ТА ЛІТЕРАТУРА}

1. Горенко-Баранівська Л. У серці - Рідна Україна (до дня народження видатного українського культурно-громадського діяча, співака і українознавця, Народного артиста України, професора Анатолія Мокренка ) // Українознавство. Число 2. 2005. Науковий громадсько-політичний, культурно-мистецький, релігійно-філософський педагогічний журнал. С. 41-44.

2. Гринів O.I. Українська нація в історичному вимірі: постановка проблеми 3 погляду націології // Збірник наукових праць науково-дослідного інституту українознавства. Київ: Поліграфічний центр «Фоліант». T. IV. С. 40-59.

3. Енциклопедія українознавство для школярів i студентів / Авт.-уклад. В.В. Оліфіренко, С.М. Оліфіренко, Т.В. Оліфіренко, Л.В. Оліфіренко. Д. Сталкер. Київ, 2001. 496 с.: іл.

4. нститут Народознавства НАН України. Шановні львів'яни та гості міста! URL: ethnoiogy.lviv.ua (дата звернення: 08.04.2019).

5. Інститут українознавства iм. I. Крип'якевича. URL: inst-ukr.lviv.ua (дата звернення: 08.04.2019).

6. Кононенко П.П. Національна ідея, нація, націоналізм // Збірник наукових праць науково-дослідного інституту українознавства. Київ: Поліграфічний центр «Фоліант», 2005. T. IV. C. 7-23.

7. Краснодемська I. Енциклопедія Українознавства у становленні та розвитку науки самопізнання // Українознавство. Науковий громадсько-політичний, культурномистецький, релігійно-філософський педагогічний журнал. Число 3. 2005. С. 107-112.

8. Крижанівська В. Українознавство в загальноосвітніх навчальних закладах (на допомогу вчителю українознавства) // Українознавство. Науковий громадсько-політичний, культурно-мистецький, релігійно-філософський педагогічний журнал. Число 3. 2005. C. $114-115$.

9. Культура і побут населення України: Навч. посібник / В.І. Наулко, Л.Ф. Артюх, В.Ф. Горленко та ін. Київ: Либідь 1991. 232 с.

10. Мельник I.A. Національне відродження в процесі утвердження суверенітету України // Збірник наукових праць науково-дослідного інституту українознавства. Київ: Поліграфічний центр «Фоліант», 2005. T. IV. С. 59-73.

11. Мирончук Ю. Дивосвіт рідної мови у творчості Дмитра Білоуса // Українознавство. Науковий громадсько-політичний, культурно-мистецький, релігійнофілософський педагогічний журнал. Число 1. 2005. С. 246-254.

12. Незламне сміле. URL: http:www.umoloda.kiev.ua/number/1197/163/42534/ (дата звернення: 25.03.2019).

13. Таровська О. Історія становлення НДІУ як віддзеркалення утвердження теорії українознавства на теренах України 90-х pp. XX ст. // Українознавство. Науковий громадсько-політичний, культурно-мистецький, релігійно-філософський педагогічний журнал. Число 1-2. 2004. С. 207-214. 
14. Токар Л. Самоідентифікація в системі самопізнання й самотворення народу // Українознавство. Науковий громадсько-політичний, культурно-мистецький, релігійнофілософський педагогічний журнал. Число 1-2. 2004. С. 164-171.

15. Токар Л.К. Зміст українознавства: системно-функціональний підхід до структурування знань // Збірник наукових праць науково-дослідного інституту українознавства. Київ: Поліграфічний центр «Фоліант», 2005. T. IV. С. 24-32.

16. Усатенко Т.П. Українознавство: міфологічний аспект // Збірник наукових праць науково-дослідного інституту українознавства. Київ: Поліграфічний центр «Фоліант», 2005. T. IV. C. 32-39.

17. Шевченко В. Філософсько освітній потенціал українознавства // Українознавство. Науковий громадсько-політичний, культурно-мистецький, релігійнофілософський педагогічний журнал. Число 1. 2005. С. 69-74.

18. Шкрібляк П. Регіональна самобутність гуцульщини в загальноукраїнському контексті: історія, сучасний стан, перспективи і проблеми // Українознавство. Науковий громадсько-політичний, культурно-мистецький, релігійно-філософський педагогічний журнал. Число 1. 2005. С. 229-240.

\section{REFERENCES}

1. Horenko-Baranivska, L. (2005). U sertsi - Ridna Ukraina (do dnia narodzhennia vydatnoho ukrainskoho kulturno-hromadskoho diiacha, spivaka i ukrainoznavtsia, Narodnoho artysta Ukrainy, profesora Anatoliia Mokrenka) [In the heart - Native Ukraine (to the birthday of a prominent Ukrainian cultural and public figure, singer and Ukrainian scientist, People's Artist of Ukraine, Professor Anatoliy Mokrenko)]. Ukrainoznavstvo - Ukrainian Studies, 2, $41-44$ [in Ukrainian].

2. Hryniv, O.I. (2005). Ukrainska natsiia v istorychnomu vymiri: postanovka problemy z pohliadu natsiolohii [The Ukrainian nation in the historical dimension: the statement of the problem from the point of view of national science]. Zbirnyk naukovykh prats naukovodoslidnoho instytutu ukrainoznavstva - Collection of scientific papers of the Research Institute of Ukrainian Studies, T. IV, 40-59 [in Ukrainian].

3. Olifirenko, V.V., Olifirenko, S.M., Olifirenko, T.V. \& Olifirenko, L.V. (2001). Entsyklopediia ukrainoznavstvo dlia shkoliariv $i$ studentiv [Encyclopedia of Ukrainian Studies for Schoolchildren and Students]. Kyiv [in Ukrainian].

4. Shanovni lviv'iany ta hosti mista! [Dear Lviv residents and guests of the city!]. ethnoiogy.lviv.ua. Retrieved from: http://ethnoiogy.lviv.ua [in Ukrainian].

5. Instytut ukrainoznavstva im. I. Kryp'iakevycha [Institute of Ukrainian Studies. I. Krypiakevich]. inst-ukr.lviv.ua. Retrieved from: http://inst-ukr.lviv.ua [in Ukrainian].

6. Kononenko, P.P. (2005). Natsionalna ideia, natsiia, natsionalizm [National Idea, Nation, Nationalism]. Zbirnyk naukovykh prats naukovo-doslidnoho instytutu ukrainoznavstva Proceedings of the Research Institute of Ukrainian Studies, T. IV, 7-23. Kyiv: Polihrafichnyi tsentr «Foliant» [in Ukrainian].

7. Krasnodemska, I. (2005). Entsyklopediia Ukrainoznavstva u stanovlenni ta rozvytku nauky samopiznannia [Encyclopedia of Ukrainian Studies in the Formation and Development of the Science of Self-Knowledge]. Ukrainoznavstvo - Ukrainian Studies, Chyslo 3, 107-112 [in Ukrainian].

8. Kryzhanivska, V. (2005). Ukrainoznavstvo v zahalnoosvitnikh navchalnykh zakladakh (na dopomohu vchyteliu ukrainoznavstva) [Ukrainian Studies in Comprehensive Educational Institutions (to assist Ukrainian teacher)]. Ukrainoznavstvo - Ukrainian Studies, Chyslo 3, 114115 [in Ukrainian].

9. Naulko, V.I., Artiukh, L.F. \& Horlenko, V.F. (1991). Kultura i pobut naselennia Ukrainy: navch. posibnyk [Culture and life of the population of Ukraine]. Kyiv: Lybid [in Ukrainian]. 
10. Melnyk, I.A. (2005). Natsionalne vidrodzhennia v protsesi utverdzhennia suverenitetu Ukrainy [National revival in the process of asserting the sovereignty of Ukraine]. Zbirnyk naukovykh prats naukovo-doslidnoho instytutu ukrainoznavstva - Collection of scientific works of the Research Institute of Ukrainian Studies, T. IV, 59-73. Kyiv: Polihrafichnyi tsentr «Foliant» [in Ukrainian].

11. Myronchuk, Yu. (2005). Dyvosvit ridnoi movy u tvorchosti Dmytra Bilousa [Divine education of native language in the works of Dmitry Belous]. Ukrainoznavstvo - Ukrainian Studies, Chyslo 1, 246-254 [in Ukrainian].

12. Nezlamne smile [Unbreakable bold]. umoloda.kiev.ua. Retried from: http:www.umoloda.kiev.ua/number/1197/163/42534/ [in Ukrainian].

13. Tarovska, O. (2004). Istoriia stanovlennia NDIU yak vidzerkalennia utverdzhennia teorii ukrainoznavstva na terenakh Ukrainy $90-\mathrm{kh}$ rr. XX st. [History of NDIU formation as a reflection of the statement of the theory of Ukrainian studies in the territory of Ukraine of the 90s of the XX century]. Ukrainoznavstvo - Ukrainian Studies, Chyslo 1-2, 207-214 [in Ukrainian].

14. Tokar, L. (2004). Samoidentyfikatsiia v systemi samopiznannia y samotvorennia narodu [Self-identification in the system of self-knowledge and self-creation of the people]. Ukrainoznavstvo - Ukrainian Studies, Chyslo 1-2, 164-171 [in Ukrainian].

15. Tokar, L.K. (2005). Zmist ukrainoznavstva: systemno-funktsionalnyi pidkhid do strukturuvannia znan [Content of Ukrainian Studies: A System-Functional Approach to Knowledge Structuring]. Zbirnyk naukovykh prats naukovo-doslidnoho instytutu ukrainoznavstva - Collection of Scientific Papers of the Research Institute of Ukrainian Studies, T. IV, 24-32. Kyiv: Polihrafichnyi tsentr «Foliant» [in Ukrainian].

16. Usatenko, T.P. (2005). Ukrainoznavstvo: mifolohichnyi aspect [Ukrainian Studies: Mythological Aspect]. Zbirnyk naukovykh prats naukovo-doslidnoho instytutu ukrainoznavstvaCollection of Scientific Papers of the Research Institute of Ukrainian Studies, T. IV, 32-39. Kyiv: Polihrafichnyi tsentr «Foliant» [in Ukrainian].

17. Shevchenko, V. (2005). Filosofsko osvitnii potentsial ukrainoznavstva [Philosophical and educational potential of Ukrainian studies]. Ukrainoznavstvo - Ukrainian Studies, Chyslo 1, 69-74 [in Ukrainian].

18. Shkribliak, P. Rehionalna samobutnist hutsulshchyny $\mathrm{v}$ zahalnoukrainskomu konteksti: istoriia, suchasnyi stan, perspektyvy i problemy [Regional identity of the Hutsul region in the Ukrainian context: history, current state, prospects and problems]. Ukrainoznavstvo - Ukrainian Studies, Chyslo 1, 229-240 [in Ukrainian].

Одержано 23.04.2019.

УДК 323.15(091)(477)]:930.1(477)«199/201»

\section{Коцур Віталій,}

кандидат політичних наук, доцент, старший науковий співробітник відділу національних меншин,

kotsurv@ukr.net

https://orcid.org/0000-0001-6647-7678

Інститут політичних i етнонаціональних досліджень ім. І.Ф.Кураса НАН України, вул. Генерала Алмазова, 8. м. Київ, 01011.

\section{DOI https://doi.org/10.31470/2415-3567-} 2019-46-232-250

\section{Kotsur Vitalii,}

Candidate of Political Sciences, Assoc. Prof., Senior Research Scientist of the Department of National Minorities

kotsurv@ukr.net https://orcid.org/0000-0001-6647-7678

I.F. Kuras Institute of Political and EthnoNational Research of the National Academy of Sciences of Ukraine 